\title{
Implementation of Lesson Study in Mathematics Learning Based on Student Cognitive Style
}

\author{
Djatmiko Hidajat \\ Universitas Veteran Bangun Nusantara \\ Sukoharjo, Indonesia \\ djatmikohidajat@gmail.com
}

\author{
Siti Maghfirotun Amin, \\ Universitas Negeri Surabaya \\ Surabaya, Indonesia \\ amin3105@yahoo.com
}

\author{
Yusuf Fuad \\ Universitas Negeri Surabaya \\ Surabaya, Indonesia \\ yusuffuad@unesa.ac.id
}

\begin{abstract}
The research on the implementation of the lessson study aims to obtain information on students' readiness in learning mathematics based on their cognitive style. There are two types of students', field dependent and field independent cognitive styles. The method of obtaining information on students' readiness in learning mathematics through this first lesson study phase is that the plan is an initial activity with the lesson study team to discuss various preparations which needed. The second stage is the process of observing during the lesson study process in the classroom, the main observation of observers at the lesson study is to emphasized when students have questions and answers between lecturers and students and when students discuss in groups. The last stage is seeing as a form of evaluation of conclusions through lecturer model expressions and various findings from all observers in order to improve and be analyzed by researchers. Information on student readiness in mathematics learning becomes a reference for lecturers' preparation in preparing the necessary tools, models or learning methods. Early preparation by the lecturer can support the peak achievement of students during learning.
\end{abstract}

Keywords- cognitive style, lesson study, mathematical characteristics.

\section{INTRODUCTION}

Generally, many people considering mathematics as a numerical problem which discus about abstract material. So that seldom like mathematics, the best solution is needed so that mathematics can be understood easily for the students who study mathematics because mathematics is actually the basis of learning for the growth and development of the brain to prioritize the logic of thinking in the face of the reality of life problems. [1] suggests that lecturers are considered as nation builders and responsible for the formation of student character. So that a lecturer always innovates in learning one of which is doing learning research to get various factors that influence their success in learning mathematics.

In the study of lesson study implementation on students' cognitive style in learning mathematics is one of the learning model efforts in order to improve the quality of the learning process. A good learning process will have an impact on improving the quality of education in accordance with what is stated

[2] Learning achievement is a realization of potential skills or capacity that a person has. Lesson study can be used as a method of exchanging ideas in the development and preparation of Mathematics learning plans. [3] states that lesson study is an effort to improve learning processes and outcomes that are carried out collaboratively and sustainably. In Indonesia Lesson study needs to be done, because it can improve the quality of education that the government has done through various training programs, generally limited to improving understanding of subject matter, while the introduction of learning methods is separated from the subject matter, making it difficult for teachers to integrate. Lesson study that is applied as a guidance model for teacher candidates is expected to improve students' ability in implementing learning strategies, [3].

Cognitive style is an affective, cognitive and psychomotor characteristic in learning that influences success in learning. Cognitive style is a learning character that is inherent in a person so that it is closely related to how to receive and process all information, especially in learning. Cognitive style divide into two style, which is Independent field cognitive style that is thinking tends to have independence of view and cognitive style of dependent filed is dependency of view. [5] Revealing that one of the ways parents can do so that their children have good achievements is by finding the child's cognitive style and accepting children according to their abilities. [5] State a person's tendency or orientation in the learning process is influenced by four learning models namely feeling, thingking, wacthing and doing are a way that someone tends to be chosen to receive information in their environment and process information. Learning requires concentration so the situation and conditions to concentrate are closely related to cognitive style.

The problem is what is the result of implementing the lesson study on the cognitive style of mathematics education students.

Mathematics is a geometry that has many branches, at a low level that arithmetic is then expanded to a higher level and many new branches are added. [6] State that mathematics has an abstract object of study, mathematics bases itself on agreements, mathematics fully uses a deductive mindset, and mathematics is imbued with the truth of consistency . [7] Asserts, mathematics is a symbolic language of deductive science that does not accept inductive proof, knowledge of order, and organized structure, from elements that are not defined, to defined elements, to akisioma or postulate and finally to the argument. According [8] mathematics is a symbolic language whose practical function is to express quantitative relationships and spatial, while the theoretical function is to facilitate 
thinking. Based on the opinions of these experts, it was concluded that mathematics is a science that studies the calculation process of algebraic operations accompanied by structured and organized requirements.

Lesson study according to [9] is a model of educating professional development through collaborative and sustainable learning studies based on the principles of collegiality and mutual learning to build a learning community. Besides, [10] state that Lesson study is a collaborative process in a group of teachers when identifying learning problems, designing a learning scenario. It can be concluded that lesson study is a learning model in improving educator professionalism that is carried out together in order to realize the performance of educators in a better direction. Own lesson study is not a learning method or strategy but lesson study activities can apply learning methods or strategies that are appropriate to the situation, conditions, and problems faced by educators.

The lesson study excellence according to [11] assert that the use of lesson study creates inquiry more collaboratively between prospective teachers and teachers and provides information on the basis of experience on how to create learning enhancements for student. "The virtue of lesson study is that it can improve skills or skills in learning activities carried out by the teacher through lesson study activities, namely learning from a lesson." Based on the superior opinion Lesson study can be concluded that can create cooperation among educators in developing learning, providing opportunities for educators to solve learning problems together, and making educators closer to communicating.

The characteristics of each individual are different, this can be seen from the way he behaves, evaluates, and thinks. The difference that persists in each individual in how to process and compile information from his experience is what is called cognitive style. [13] Asserting that "cognitive style is a self-generated, transient, situationally determined conscious activity that uses learners to regulate and to regulate, receive and transmit information and ultimate behavior." Which means cognitive style is a process of control or style which is self-management, as a situational intermediary to determine conscious activity so that a student is used to organize and organize, receive and disseminate information and ultimately determine the behavior of the learner. According to [14] based on this method of grouping cognitive styles can be distinguished from independent and field dependent fields. Cognitive style is a bridge between cognition and action that shows a person's personality. So it can be concluded that cognitive style is the way every individual receives, organizes, responds, processes information and compiles it based on the experiences he experiences.

\section{METHODS}

The research in the implementation of lesson study on the cognitive style of mathematics learning students aims to reveal the character of the students in their preparation until the process of mathematics learning takes place. The subjects in this research were the students of Veteran
Bangun Nusantara University of Sukoharjo who took Kapita Selekta courses. Students are given a test to find out their cognitive style. To find out the cognitive style of students, the Embedded Figures Test (GEFT) instrument was used. These test results are used to determine research subjects that are included in the independent field cognitive style or field dependent cognitive style.

In the Embedded Figures Test instrument (GEFT) was given a complex picture, then students were asked to thicken a simple picture located in the complex picture. Simple images found must be exactly the same, both in size and direction with one of the images set on the back of the GEFT. If a complex picture contains more than one simple image in question, then the student simply thickens one picture, but meets the predetermined requirements of the same size, shape and direction. The main instrument in this study is the researcher himself. Therefore, when collecting data in the field, researchers participated throughout the research process and actively participated in research subject activities related to data collection through the expression of all observers when they saw.

This research is to find out the cognitive style characteristics of students in solving mathematical problems. Data collection is done by giving questions to students relating to secondary school mathematics. From the results of the students' work they presented as data information recorded by observers through observation. To get an overview of the cognitive style characteristics of students in solving high school math problems ..

\section{RESULTS AND DISCUSSION}

Planning activities were carried out after the lesson study team was formed, there were four lecturers in the lesson study team, namely Djatmiko Hidajat, Afif Afghohani,Isna farahsanti, and Annisa Prima Exacta. Lesson study is carried out in three stages: plan, do and see. In the open of lesson study 1, 2, and 3 all in the Kapita Selekta Secondary School course with the material in place of position of distance, point, line, and field, in the second open with the rank, root, and logarithm material, and in the third open linear program. Of the three times the implementation of open lesson study was carried out in the same place and the same time with an average time interval of one to two weeks, this happened because of the density of activities of each lecturer involved there.

Plan is the beginning of every open lesson activity that aims to design learning that can teach students, how to enable students to actively participate in learning. This plan starts from the planning analysis that will be carried out in learning. Furthermore, the members of the lecturer team who are involved together find a solution to the problems raised by the lecturer model as outlined in the lesson plan or lesson plan, teaching materials in the form of learning media and student worksheets prepared before do.

Do is the implementation stage to implement the learning design that has been formulated in the planning stage. The model lecturers are the researchers themselves who will implement the lessons in lesson study with the focus of observation on students' cognitive style. The 
cognitive style of students has been found and the discussion group membership is determined based on the GEFT method before the open lesson study begins. At this stage all observers observe all student activities from the beginning to the end of the lecture. Observer is always looking for positions that are considered strategic for observation and also taking documents both in picture and video.

See is the final stage of each open lesson study where all observers provide information and input to the discussion forum after the lecturer model presents a presentation regarding the activities of the open lesson that has been carried out, this activity is guided by the moderator. Here are some information snippets from the observers with the code $\mathrm{O}_{\mathrm{i} . \mathrm{j}}=$ observer to-i in open lesson to-j

$\mathrm{O}_{1.1}=$ No. 7 students in group 2 in working on the questions were very focused on their work with little discussion.

$\mathrm{O}_{1.1}=$ Student number 13 when working on the questions in front is very coherent according to the example given by the lecturer.

$\mathrm{O}_{2.1}=$ Student number 2 is cool by reading the hand out from the material delivered by the lecturer so that it seems not to focus on the lecturer explanation.

$\mathrm{O}_{2.1}=$ Student no. 16 when the discussion took place he was seen waiting for his friend's answer this thing was seen he often twirled his coffee sam

$\mathrm{O}_{3.1}=$ Student number 9 when asked questions answered confidently while showing the reason.

$\mathrm{O}_{1.2}=$ When the lecturer gave a question in the discussion, no. 5 answered quickly with the correct answer, but the lecturer spontaneously gave a ballpoint gift and immediately got his pocket.

$\mathrm{O}_{1.2}=$ Student number 17 was seen taking his bag a few meters away from him then opening the bag apparently taking aqua glass, I thought that he wanted to drink it turned out to be a friend who looked thirsty because he immediately stopped after more than aqua glass.

$\mathrm{O}_{2.2}=$ Group 4 seems to have more discussion life than the other groups.

$\mathrm{O}_{2.2}=$ Student no. 2 is very cool with the job and after the new finish is given to the other members who are cool with their work but not finished yet.

$\mathrm{O}_{3.2}=$ Student no. 6 had a chance to argue with no. 8 when discussing maintaining their opinions, even though after being presented it turned out to be the same principle.

$\mathrm{O}_{1.3}=$ Student number 1 representing group 1 when presenting the results of his work is very coherent and explains that it is easy to be easily understood by others, after I see the results of his work are actually short but the explanation in front is very long.

$\mathrm{O}_{1.3}=\mathrm{I}$ am interested in student number 14 how to wear it neatly the way to sit also looks polite and smiles a lot, when I was asked for a discussion, he first smiled and then answered his friend's question.

$\mathrm{O}_{2.3}=\mathrm{In}$ groups 1 and $2 \mathrm{I}$ observe them more quiet than groups 3 and 4 .

$\mathrm{O}_{3.3}=$ Student number 12 when working in front of the lecturer then commented on it because the answer was coherent as the lecturer gave and then he was given a compliment he seemed blushed and cool again with his notes.

$\mathrm{O}_{3.3}=$ Student number 4 was late but after a while attending the lecture there was a question from the lecturer instead he raised himself to answer, after I approached he turned out to bring a book reference other than the lecturer handout.

From the data obtained, it shows that the individual characteristics of the field dependent cognitive style in the data O1.1, No.13, O2.1, No.16, O1.2, No.17, O2.2, group 4, O1.3, No.14, O2.3, groups 3,4, O3.3, No.12 have a tendency to be easier in responding to external stimuli, and in contrast to the cognitive field independent style in data O1.1, No.7, O2.1 , No.2, O3.1, No.9, O1.2, No.5, O2.2, No.2, O3.2, No.6, O1.3, No.1, O2.3, group 4, O3.3, No.4.

\section{CONCLUSION}

Cognitive style is bipolar meaning that has advantages and disadvantages, namely not showing the superiority of one cognitive style on other cognitive styles. Each cognitive style has a positive value in a particular situation, or vice versa tends to have a negative value in other situations. In learning with a particular model, the students' advantages are seen in accordance with the different characteristics they have. So it can be said that cognitive style is the way each individual receives, organizes, responds, processes information and compiles it based on the experiences. It can be explained by the cognitive style of students as the results of the implementation of lesson study as follows:

\section{Field independent cognitive style:}

1. More confident than the knowledge he already has.

2. Initial knowledge is difficult to change with the arrival of new knowledge that is similar.

3. In learning tends to be individual.

4. More happy with personal appreciation.

5. Happy with the competition.

6. Smart in analyzing facts.

Field dependent cognitive style:

1. In learning always guided by the existing order.

2. Lack of confidence when you don't understand something.

3. High social level.

4. Like working together.

5. Discipline and courtesy.

6. Communicative 


\section{REFERENCES}

[1] Al-Snafi. A E, Bioactive components and Pharmacological effects of Canna indica-an Overview. ijpt. Vol :5(2) pp 71-75, 2015.

[2] Exacta, A. P., \& Hidajat, D. LEVEL OF ANXIETY STUDENTS EXTEND THE SEMESTER END EXAMINATION. Edudikara, ISSN: 2541-0261, 2 (3), 243-250, 2017.

[3] Hidajat, D., Wulandari, A. A., \& Susilowati, D. EFFECT OF CAR MINIATURE USE ON MATHEMATICAL LEARNING ACHIEVEMENT. Edudikara, ISSN: 2541-0261, 3 (1), 14-22, 2018.

[4] Rahayu, P., Mulyani, S., \& Miswadi, S. S. Development of Integrated Science Learning by Using Learning Model Problem Base Through Lesson Study. Journal of Indonesian Science Education, 1 (1), 63-70, 2012.

[5] Ramlah, Dani Firmansyah, H. Z. The Influence of Learning Style and Student Activity on Mathematics Learning Achievement (Survey of Public Middle Schools in Klari Subdistrict, Karawang Regency). Scientific Journal of Solutions, 1 (3), 68-75, 2014.

[6] Hidajat, D., Susilowati, D., \& Wijayanti, M. THE INFLUENCE OF COOPERATIVE INTEGRATED READING AND COMPOSITION LEARNING MODELS ON MATHEMATICAL LEARNING ACHIEVEMENT OF GROGOL 3 STATE SCHOOL OF HIGH SCHOOL, SUKOHARJO. The Math Educator Nusantara Journal, ISSN: 2459-97345, 1 (2), 195-203, 2015.

[7] Heruman. Mathematics Learning Model. Bandung: Teenagers Rosdakarya. http://www.westga.edu/-distance/liu23.html. Retrieved March 10, 2018, 2015.

[8] Abdurahman. Education. Jakarta: PT Asli Mahasatya, 2010.

[9] Supranoto, H. Application of Lesson Study in Improving Teacher's Pedagogic Competency at Bina Mulya Gadingrejo High School in the 2015/2016 Academic Year. JOURNAL OF PROMOTION Journal of Economic Education UM Metro, 3 (2), 21-28, 2016.

[10] Susilo, et al. Lesson Study Based on Conservative Teachers Towards Innovative Teachers. Malang: Bayumedia Publishing, 2009.Rusman. Learning Models. Developing Professional Teachers, Jakarta: Raja Grafindo Persada, 2011.

[11] Sugiharto, B., Prayitno, B. A., \& Widoretno, S. Types of Professional Development and Conception of Lesson Study Learning Community in Science Teachers of Surakarta City Middle School. Proceedings of Biology Education Conference, 13 (1), 63-69, 2016.

[12] Ngilawajan, D. A. The Process of Thinking High School Students in Solving Mathematical Problems Derivative Material Judging From the Cognitive Style of Independent Fields and Dependent Fields. Pedagogia, 2 (1), 71-83. https://doi.org/10.21070/pedagogia. v2i1.48, 2013.

[13] Ratumanan, T. The Influence of Learning Models and Cognitive Style on Junior High School Mathematics Learning Outcomes in Ambon City. Journal of Basic Education, 5 (1), 1-10, 2003. 